\title{
Impact of Neonicotinoids to Aquatic Invertebrates-In Vitro Studies on Mytilus galloprovincialis: A Review
}

\author{
Maria Pagano ${ }^{1}\left(\mathbb{D}\right.$, Alzbeta Stara ${ }^{1,2,3}$, Valbona Aliko ${ }^{4}$ and Caterina Faggio $1, * \mathbb{C}$ \\ 1 Department of Chemical, Biological, Pharmaceutical and Environmental Sciences, University of Messina, \\ Viale Ferdinando Stagno D’Alcontres 31, 98166 Messina, Italy; mpagano@unime.it (M.P.); \\ staraa01@frov.jcu.cz (A.S.) \\ 2 South Bohemian Research Center of Aquaculture and Biodiversity of Hydrocenoses, \\ Faculty of Fisheries and Protection of Waters, University of South Bohemia in Ceske Budejovice, \\ 37005 Ceske Budejovice, Czech Republic \\ 3 Research Institute of Fish Culture and Hydrobiology, Zatisi 728/II, 38925 Vodnany, Czech Republic \\ 4 Department of Biology, Faculty of Natural Sciences, University of Tirana 25/1, Tirana, Albania; \\ valbona.aliko@fshn.edu.al \\ * Correspondence: cfaggio@unime.it; Tel.: +39-090-6765213
}

Received: 4 September 2020; Accepted: 11 October 2020; Published: 15 October 2020

\begin{abstract}
The use of pesticides in agriculture has always had a strong impact on environmental contamination. Since the 1990s, neonicotinoids have grown increasingly more popular, targeting specific receptors for insects, especially bees, which is why the use of some neonicotinoids has been banned. Much is known about the effects they have on insects, but very little about the effect they can have on non-target organisms. Several studies have shown how these neonicotinoids interact negatively with the normal physiology of aquatic organisms. For the genus Mytilus, even though the neonicotinoids did not show an interaction with specific receptors, a chronic and acute exposure to them causes damage. In these animals, a reduced production of byssus, alteration of the normal antioxidant systems and tissue damage have been found. Therefore, an analysis of the entire ecosystem in which the pollutant enters is of great importance in evaluating any possible alterations.
\end{abstract}

Keywords: neonicotinoids; mussels; pesticide

\section{Introduction}

The worldwide use of pesticides in agriculture, a practice that has been going on for decades, means that residues of pesticides, most often substances of the group of insecticides and herbicides, are commonly found in many environments, from cultivated fields to rivers and oceans, and even in urban environments [1,2]. While insecticides are useful for controlling and avoiding pest infestations, it is also true that the pollution they cause is one of the many problems that our society must face. This is because the extreme toxicity of most of these chemical substances, whether natural or artificial, affects not only the target organisms, but also many other species of animals, albeit obviously to different degrees [2,3]. In fact, insecticides are able to alter the ecological structure of the soil in which earthworms and arthropod communities live, and in turn affect birds and other vertebrates that feed on these organisms. Additionally, residues that float in water for short or long periods of time can decimate zooplankton, aquatic crustacean larvae and insects, or impair the growth and development of tadpoles and fish. On the other hand, just because insecticides are designed to kill insects does not mean that they are excluded from killing other animals, including humans. It is therefore necessary for 
society to recognize the dangers and risks of their use, so that precautionary measures can be taken to mitigate their negative effects on the environment and human health [2-5].

In general, the toxicity and specificity of insecticides are a consequence of their mode of action on the various cell types and physiological mechanisms of an organism [2]. There are neurotoxic insecticides that act on the neurotransmission system, causing brain death or affecting the motor system through paralysis, seizures, hyperactivity and spasms. Other insecticides act as respiratory inhibitors; these hinder the oxidative phosphorylation that occurs in the mitochondria, which is common to many organisms. Obviously, the effects change according to the class of organisms considered. For example, organic compounds and propargite used against mites are particularly toxic for all aquatic organisms, but seem relatively harmless to terrestrial vertebrates, probably due to their developed detoxification capacity. Other insecticides can inhibit growth, as in the case of arthropods, whose life cycle of development and metamorphosis is altered and blocked, or can be genotoxic [3]. Other substances, on the other hand, act on the biosynthesis of chitin, a component of the exoskeleton. Lastly, there are insecticides that are highly toxic to the stomach and gut, causing destruction of internal tissues.

Why are aquatic organisms particularly susceptible to insecticides? They share not only the same neurological and respiratory mechanisms with insects, but also the same detoxification system, which is deficient in both cases [2]. This is because aquatic invertebrate organisms are ancestral; therefore, their cytochrome P450 isoenzymes and their monooxygenases are somewhat inefficient. Consequently, these organisms are unable to degrade most of the toxic compounds that enter their body $[2,6]$. On the other hand, terrestrial organisms have developed more efficient isoenzymes and are able to cope with the excess of toxic substances present in the environment [2].

Among the insecticides that are commonly used in agriculture today, those that create a lot of interest in the scientific community, due to possible environmental risks, are certainly neonicotinoids. These insecticides are introduced at the seed level and then spread throughout the plant body, protecting it for several months after sowing $[7,8]$. A part of the active principle that is not absorbed by the crop is lost in the form of dust during sowing [8,9]. This dust may be sufficient to cause direct mortality in bees flying in that area [8-10] and also settles along the vegetation found at the edge of the field $[8,11]$, then reaching bodies of water.

Neonicotinoids target a very specific part of the insect brain, namely the one responsible for learning and memory. In fact, in bees, the accumulation of neonicotinoids in the brain causes neuronal dysfunctions that limit the ability of these organisms to learn and remember [12,13]. Additionally, residues of neonicotinoids and other insecticides remain in honey and enter our diet $[9,12]$. No less important is the presence of little data regarding the effects of neonicotinoids when interacting with other stressors, such as other pesticides, diseases and eating disorders, aspects that undoubtedly influence the health of bees $[8,14,15]$. In fact, observing different colonies, the effects of varying intensity can be recorded, and these differences could be linked to stress factors or diseases on a genetic basis that alter the activity of enzymes involved in metabolic and detoxification processes, or to environmental factors, such as climate, which can modify the quality of food resources by negatively affecting the immunity of bees [16]. For these reasons, national monitoring networks have been set up.

Another problem with neonicotinoids, according to some research, is that they can persist in the environment for about 20 years. They settle at ground level and when the aquifers change, the substances soaked in the ground are absorbed by the plants and brought back down in the soil, almost in a cyclic manner. Therefore, we understand very well that this is a contamination that lasts for years and that cannot be immediately stopped only by prohibiting the use of specific neonicotinoids. In fact, banning a class of pesticides leads to an attempt to replace the known substance with a series of substances that have not yet been analyzed, which perhaps after years will be harmful and will also be banned. For example, new insecticides have recently been produced that are supposedly different from neonicotinoids, but which in fact simulate them in the active ingredients. In fact, the toxic part of neonicotinoids is caused by a ring with bound nitrogen and chlorine, which is replaced in new insecticides by a ring that binds fluorine instead of chlorine, which is even worse, given the chemical 
characteristics of this element. Another myth is that agricultural production will collapse without the use of pesticides at current levels $[17,18]$. If this is true, it is because we were the ones who designed agriculture that revolves around pesticides-we do not necessarily have to follow this path. In some analyzed cases, such as the tanning of corn, it has in fact emerged that by using traditional techniques, there may be small variations due to seasonality, but these do not compromise the final results. More than the use of pesticides, therefore, we can speak of their abuse [18]. Just think that every single farmer can use, in accordance with the regulation, a quantity of neonicotinoids that does not exceed the threshold value. However, that same regulation may no longer apply when many farmers use these insecticides at the same time for an extended amount of time. Dondero et al. (2010), using the model organism Mytilus galloprovincialis, noted and demonstrated that, when tested together, imidacloprid and thiacloprid induced different toxicological dynamics than the effects that resulted when administered individually. We must realize the importance of bees, other pollinators, and soil insects that are fundamental for the organic cycles, and in general for the balance of the environment in which we live.

Honey consumption is not the only way in which neonicotinoids can affect human life. In fact, research conducted by the European Food Safety Authority (EFSA) showed that two insecticides, such as acetamiprid and imidacloprid, can have effects on the human nervous system during intrauterine development. More precisely, these substances can affect the development of neurons and brain structures associated with critical functions such as learning and memory, similar to what happens in bees [15]. Furthermore, case-control studies have been published that describe, in all cases and with adequate methodology, significant associations between chronic exposure to neonicotinoids and the risk of developmental alterations, such as Fallot's tetralogy, a congenital heart disease, anencephaly, autism spectrum disorders, memory and motor alterations. Given this limited evidence, the biological effects of neonicotinoids on humans have yet to be fully elucidated. Despite this, experts believe that health concerns are justified. Hence, there is an immediate need and importance of conducting studies on this class of pesticides, which can be possible thanks to the presence of model organisms such as Mytilus galloprovincialis.

\section{Neonicotinoids: Dangerous Insecticides}

Over the past two decades, a new class of insecticides has emerged that are widely used globally today: neonicotinoids. The neonicotinoids, developed and for the first time registered in the early 1990s, as well as the phenyl-pyrazole fipronil, are insecticides capable, regardless of the method of application, of penetrating the tissues of the plant and then spreading to all its parts, thus making them toxic to any insect, and protecting them both from the direct attack of insects and, indirectly, from the viruses of which these organisms are vectors [19]. Neonicotinoids are neurotoxins that act as agonists of the nicotinic receptors for acetylcholine, while fipronil, also a widely-used insecticide, binds to the receptors for $\gamma$-aminobutyric acid. In both cases, the signal transduction process is affected. Their action, therefore, induces a continuous excitation of neuronal membranes, causing paralysis and depletion of cellular energy, as well as death of the target insects [19,20]. An example of a neonicotinoid is thiacloprid, used mainly against aphids; its mechanism of action also includes in this case the stimulation of nicotinic receptors for acetylcholine. Due to its stability and solubility, thiacloprid potentially puts aquatic organisms at risk. In fact, the effects are visible on various marine organisms as well as freshwater organisms, including carp, which, thanks to the physiological and biochemical differences of the embryonic and larval stage, was used for toxicity tests in the early stages of development [20].

Obviously, the binding sites present on nicotinic receptors are different, depending on whether we are talking about vertebrates or invertebrates; the former in fact have a lower number of nicotinic receptors with high affinity for neonicotinoids, and show differences in properties and structure at the level of the subunits [19]. This partly explains the high selectivity of neonicotinoids for invertebrates and the lower, at least so supposed, toxicity for vertebrates. 
The voltage-dependent calcium channels are also involved in the insecticidal activity of the neonicotinoids. This bond strength is conferred by a single molecular conformation [19,21]. However, the interaction of this conformation with the receptor could vary depending on the chemical substituents and the species considered. In general, in fact, these insecticides have the ability to bind multiple sites [19]. The metabolism of the main neonicotinoids can be divided into two phases: the first, found in plants and small mammals, depends on cytochrome P450 and includes a series of reactions such as dimethylation, reduction, hydrolysis, hydroxylation, and opening of ring structures. The second phase mainly involves the formation of conjugates, which differ between plants and animals [19,22-24]. Some metabolites are common to the different neonicotinoids, while others are specific [19,23-27].

Several types of neonicotinoids are available on the market today, such as acetamiprid, nitenpyram, and dinotefuran, as well as cis-neonicotinoids, i.e., isomers in which the nitro or cyano group has a cis rather than a trans orientation. This structural difference obviously has repercussions on toxicity $[19,28]$. Furthermore, neonicotinoids are known to be synergistically toxic when occuring together or combined with other P450 monoxygenase enzyme inhibitors [29-31]. Just to mention one, a combination of neonicotenoids with trifloxystrobin can significantly increase the kill rate of leaf beetle (Phaedon) larvae [32]. Since natural ecosystems generally suffer from xenobiotic mixtures, it is of great importance to consider the effects of their possible interactions on aquatic biota.

Some insecticides are more dangerous than others. For example, since 2013, after the publication of a study that demonstrated the high risk for bees and beyond, the European Union has imposed restrictions on the use of some neonicotinoids, especially imidacloprid, another important feature of neonicotinoids and of fipronil is that they are relatively persistent [19].

\section{Mytilus galloprovincialis: A Suitable Model Organism for the Study of Neonicotinoids}

The persistence of the neonicotinoids, while on the one hand offers the possibility of long-term protection of agricultural activity, on the other hand makes us worry about disposal times and it is essential to see the effects of these pollutants on marine organisms such as bivalve mollusks. More precisely, physiological mechanisms that regulate stress-related responses are well characterized in species belonging to the genus Mytilus [28-35], which can accumulate and tolerate in their high levels of xenobiotics [36-43]. Particularly widely distributed in the Mediterranean Sea, both in coastal areas and in estuaries, is M. galloprovincialis, which is continuously exposed to anthropogenic compounds and is considered a valid bioaccumulator [38]. They allow, through the analysis of body tissues and fluids, to accurately and reliably detect physiological, behavioral, cellular, biochemical, and molecular indices [38,43,44]. The choice of mussels as a model species, therefore, is based on their wide distribution, their high sensitivity to stress factors and their eating habits, which predispose them to the absorption and accumulation of a wide spectrum of chemicals present in the water $[35,45,46]$. They are, in fact, excellent filters, they are able to cope with extreme variations in temperature and anoxia, they are able to interrupt the filtering system in non-optimal environmental conditions [47-52], and they have the ability to concentrate contaminants in their tissues and organs more than a million times the concentration of these same substances in their habitat [53,54]. All these characteristics make them suitable for studying the effects of traditional (drugs, pesticides etc.) and new pollutants, the so-called "emerging" ones, from endocrine disruptors to nanotoxic compounds [52,55-57]. They, together with other crustaceans [58], can also be used to test hypolipidemic drugs, antidepressants, antiepileptics, and antibiotics, as well as non-steroidal anti-inflammatory, antipyretic, and analgesic drugs [59-66]. Also important are the studies on preservatives, i.e., natural or synthetic ingredients added to products such as foods, drugs, and personal care products to prevent spoilage, microbial growth, or unwanted chemical changes [67].

Depending on the contaminants, different parameters are obviously evaluated, such as the stability of the lysosomal membranes, the activity of catalase and glutathione S-transferase, and the accumulation of malondialdehyde and lipofuscin, to analyze the pro-oxidant effects and the detoxification responses, the activity and the appearance of primary DNA damage linked to neuro and genotoxic lesions $[34,68]$, 
as well as the excessive cellular production of reactive oxygen species, usually associated with the peroxidation of biological lipid membranes [35,67]. Reactive oxygen species are normally produced during aerobic life and other physiological processes, but under normal conditions, their level is regulated by antioxidant systems. When a compound increases the production of reactive species or causes the depletion of low molecular weight antioxidant molecules, an inactivation or reduced expression of antioxidant enzymes occurs, ROS production increases and oxidative stress occurs [69-72]. For this reason, ROS level estimation is widely used to assess the effects of specific pollutants on physiological responses such as mortality, shell, and tissue growth [72,73] and regulation cell volume $[37,72,74]$.

Sometimes, the activity of cellular receptors can be considered, as in the case of mussels exposed to microplastics, which have shown enrichment of the signaling pathway of NOD-type receptors. These act as intracellular sensors, recognizing the pathogenic patterns that enter the cell through phagocytosis, the molecules associated with the damage produced during cellular stress, and the activation of non-infectious inflammatory responses [75]. Significant changes were also found at the level of the transcriptional regulation of genes that play an important role within the cell, for example genes that code for anti-apoptotic factors or factors involved in autophagy processes. These processes, such as calcium metabolism and homeostasis, cellular signaling, and stress responses by the endoplasmic reticulum [76], as well as ion and nutrient levels, may also be affected, since in the presence of contaminants, mussels could keep the valves closed to avoid the accumulation of these substances, and this could reflect a reduced ability to filter effectively [77].

To study the effects of contaminants, however, we must also know the routes by which these substances enter in organisms. In fact, contaminants can enter mussel tissues through food, respiration, or transport across biological membranes $[54,78,79]$. If they enter with food, the most commonly-used target tissue to study their effects is the digestive gland, which includes numerous blind-bottomed epithelial tubules composed mainly of basophilic and digestive cells. Basophilic cells have a highly developed rough endoplasmic reticulum and many secretory granules, which play an important role in enzyme production and secretion; digestive cells, on the other hand, have a well-developed endocytic lysosomal vacuolar system, which includes heterophagosomes, heterolysosomes, and residual bodies, responsible for intracellular digestion processes $[38,80]$. In particular, the lysosomes of digestive cells are also responsible for the sequestration and detoxification of toxic metals and organic pollutants $[38,81,82]$.

Gills are another target organ that are particularly subject to the accumulation of toxic molecules because they are involved in both feeding and breathing processes; they are also of particular interest because they represent a barrier between the mussel's body and the surrounding aquatic environment $[67,83,84]$.

Another possibility is that xenobiotics enter mussel tissues through biological membranes; in this case, most of the ions are able to penetrate the cytoplasm only with the help of proteins known as "membrane transporters," because the inorganic ions are hydrophilic, while the outer surface of the plasma membrane is hydrophobic. Once inside the cell, the ion must be collected by another ligand to prevent its diffusion outside, and the set of these ligands constitutes a system of "kinetic trapping," whose effectiveness depends on the bond strength [54].

As regards excretion, mussels and bivalve mollusks in general use various mechanisms to eliminate contaminants from their bodies. The overall process is species-specific as well as organ and tissue-specific, and finally ligand-specific [54]. Pollutants, such as metals, found in lysosomes are excreted by exocytosis of the vacuolar content, by elimination from renal podocytes or by diapedesis of entire granules in the urinary tract, as occurs for example in Mytilus edulis $[54,85]$. Excretion can also occur through the integument, feces $[54,85,86]$, the shell, or the release of gametes $[54,87]$.

Pesticides, in particular neonicotinoids, are among the xenobiotics internalized and possibly excreted by organisms. To date, very little is known about the mechanistic effects that could be caused by neonicotinoids, or about protective and non-protective biological responses [88]. For this reason, and also considering the widespread use of these insecticides, it is necessary to conduct studies to better 
assess the risks of these substances for non-target organisms [89]. It is certainly important to analyze a large number of organisms and species, because each will show a different sensitivity [90], since there could be wide variations in the binding affinity between neonicotinoids and nAChR [91]. However, numerous studies have shown, through the results achieved, that an excellent model organism for the study of neonicotinoids is Mytilus galloprovincialis, which allows us to evaluate various physiological parameters and consequently the effect of the insecticides of interest. Many of these studies have had as a subject one of the most powerful and widespread neonicotinoids, namely thiacloprid. It is the active ingredient of various insecticides, such as Biscaya, Calypso, and Proteus, used to control a variety of chewing and sucking insects [92-94].

Thiacloprid is capable of altering some physiological parameters, influencing the rate of vitality and mortality of the cells, and modifying the growth and production of biomass [91]. New data have recently been examined by the European Food Safety Authority (EFSA), which further demonstrated that this insecticide can have toxic effects on bees' reproduction and can cause many risks for groundwater. For this reason, the EU has decided not to renew the authorization (expiring at the end of April 2020) for thiacloprid.

Even though few studies have been carried out on M. galloprovincialis, evidence of toxic effects on organs such as gills and digestive gland and on antioxidant control systems such as SOD and CAT of the animal exposed to sublethal concentrations of both the active ingredient thiacloprid and the commercial product calypso 480 SC, are reported [93]. Stara et al. (2020), in a study conducted on M. galloprovincialis evaluating the toxic effects of 20 days exposure to concentration of $7.77 \mathrm{mg} / \mathrm{L}$ and $77.70 \mathrm{mg} / \mathrm{L}$ Calypso 480 SC insecticide, followed by a 10-day recovery period in uncontaminated seawater, reported a significantly increased of the mortality rate in hemolymph cells and the digestive gland. Furthermore, the cells of the latter organ were no longer able to regulate their volume. This exposure significantly reduced hemolymphatic parameters, such as $\mathrm{Cl}^{-}$and $\mathrm{Na}^{+}$levels, influenced the activity of the superoxide dismutase (SOD) enzyme at the digestive gland level and the catalase enzyme at the gill level, and finally caused histopathological changes in both organs [89]. Regarding histological damage, M. galloprovincialis showed an accumulation of lipofuscin, the presence of focal points of necrosis, an overproduction of mucus and the onset of infiltrative inflammation. It is interesting to note that some alterations persisted even after the recovery period in uncontaminated water, especially for the parameters of electrolytes in the hemolymph $\left(\mathrm{K}^{+}, \mathrm{Na}^{+}, \mathrm{Ca}^{2+}\right.$, lactate dehydrogenase, glucose).

Not only thiacloprid, but other neonicotinoids can also be used as subjects for these studies. For example, Dondero et al. (2010) analyzed both thiacloprid and other substances, such as imidacloprid and acetamiprid, using the model organism M. galloprovincialis. In this case, they did not report any mortality after $96 \mathrm{~h}$ of exposure up to $10,000 \mu \mathrm{g} / \mathrm{L}$ [91]. However, there was a decrease in the stability of the lysosomal membrane at the level of the gonads [88,91]. An important finding was that they observed different effects by the various neonicotinoids on the activity of the acetylcholinesterase enzyme present in the gills. In fact, exposure to 100 and $1000 \mu \mathrm{g} / \mathrm{L}$ of imidacloprid significantly reduced the activity of the enzyme, while treatment with thiacloprid significantly improved it at $1000 \mu \mathrm{g} / \mathrm{L}$ but not at 0.1 and 10,000 $\mu \mathrm{g} / \mathrm{L}$ [91]. Despite this, even more interesting was the fact that, when tested together, imidacloprid and thiacloprid induced different toxicological dynamics, as demonstrated by the different transcriptomic and proteomic profiles [86]. This result, obtained on the model organism M. galloprovincialis, has shown that compounds characterized by the same mode of action can also determine different toxicological dynamics if administered in the form of a mixture; hence, the possibility of recognizing inconsistencies when classifying pesticides based on their mode of action [88,95], especially in the context of risk assessment for humans and environment. According to the Risk Science Institute of the International Life Sciences Institute (ILSI), a common mechanism exists only if the two components cause the same critical effect, if they act on the same molecular target and on the same target tissue, if they have the same pharmacological mechanism of action, and if they share the same toxic intermediate $[88,96]$. To classify pesticides, the entire cascade of molecular and biological events should therefore be considered. 
The species belonging to the genus Mytilus include sessile organisms that anchor themselves to the substrate producing byssus, that is, collagen fibers whose number and length can vary according to environmental conditions $[93,97,98]$. Hence, the possibility of considering this fibrous structure as an evaluation parameter for the effects of pesticides. In fact, a great deal of energy is required to produce the fibers, which requires opening the valves. If the environmental conditions are favorable, this opening mechanism is not a problem. However, when all tissues are directly exposed to the external environment, if pollutants are present, the body easily comes into contact with xenobiotics or undergoes oxidative stress $[93,98,99]$. In this case, the mussels protect themselves by closing their shells and slowing down the metabolism, thus facing unfavorable conditions [92,98,100-102]. Therefore, they reduce or completely block the formation of fibers [93,98,100]. A study by Roberts (1975) is based on this very parameter. The model organism Mytilus edulis was exposed to a quantity of pesticides and PCBs (polychlorinated biphenyls), many of which, if present at high concentrations, cause a reduction in the formation of byssus [97]. The study revealed that the sensitivity of mussels increases with increasing temperature and decreases with increasing size. Among the various pesticides used, endosulfan was found to be the most toxic, causing a 50\% reduction in byssus after $24 \mathrm{~h}$ of exposure at a concentration of $0.45 \mathrm{mg} / \mathrm{L}$. Metaphonate, on the other hand, proved to be the least toxic and did not at all influence the formation of the byssus despite exposure up to $30 \mathrm{mg} / \mathrm{L}$. The probable cause of these effects on the production of collagen fibers is a reduction in the activity of the foot, although it is possible that interference on multiple levels may occur [97].

The above-mentioned studies give a clear evidence on the importance of M. galloprovincialis as a model organism, due to its ability to display physiological, behavior, cellular, and molecular alterations (Table 1). That is, it allows us to visualize variations on multiple levels, and therefore, to examine numerous pesticides, each with its own target.

Table 1. List of pollutants that have been tested, with the organs analyzed for each substance and the type of analysis carried out on Mytilus galloprovincialis.

\begin{tabular}{|c|c|c|c|}
\hline Xenobiotics & Target Tissues & Assays & References \\
\hline $\begin{array}{l}\text { Acrylamide } \\
\text { (organic compound) }\end{array}$ & $\begin{array}{l}\text { Digestive gland, gills, } \\
\text { and gonads }\end{array}$ & $\begin{array}{l}\text { Activity of } \\
\text { ethoxyresoruphine-O-diethylase } \\
\text { (EROD), catalase, and glutathione } \\
\text { S-transferase enzymes }\end{array}$ & $\begin{array}{l}\text { Larguinho } \\
\text { et al., } 2014\end{array}$ \\
\hline $\begin{array}{l}\text { Caffeine } \\
\text { (organic compound) }\end{array}$ & $\begin{array}{l}\text { Digestive gland, gills, } \\
\text { and hemolymph }\end{array}$ & $\begin{array}{l}\text { Stability of the lysosomal membrane of } \\
\text { hemocytes and activity of the hydrolase } \\
\text { N-acetyl- } \beta \text {-hexosaminidase enzyme; } \\
\text { lipid peroxidation and } \\
\text { malondialdehyde; activity of } \\
\text { glutathione S-transferase, catalase, and } \\
\text { acetylcholinesterase enzymes; } \\
\text { DNA integrity }\end{array}$ & $\begin{array}{l}\text { Capolupo } \\
\text { et al., } 2016\end{array}$ \\
\hline $\begin{array}{l}\text { Buscopan plus and } \\
\text { Mesulid (drugs) }\end{array}$ & Hemolymph & $\begin{array}{l}\text { Stability of the lysosomal membrane of } \\
\text { hemocytes; cytogenetic analysis for } \\
\text { DNA integrity }\end{array}$ & $\begin{array}{l}\text { Politakis } \\
\text { et al., } 2018\end{array}$ \\
\hline $\begin{array}{l}\text { Paracetamol, Diclofenac, } \\
\text { Ibuprofen, Ketoprofen } \\
\text { and Nimesulide (drugs) }\end{array}$ & Digestive gland and gills & $\begin{array}{l}\text { Measurement of the } \\
\text { granulocytes/hyalinocytes ratio, } \\
\text { stability of the lysosomal membrane of } \\
\text { hemocytes, phagocytosis activity, } \\
\text { accumulation of lipofuscin; activity of } \\
\text { the enzymes acyl-CoA oxidase and } \\
\text { acetylcholinesterase, catalase, } \\
\text { glutathione S-transferase, glutathione } \\
\text { peroxidase and glutathione reductase; } \\
\text { DNA integrity }\end{array}$ & $\begin{array}{l}\text { Mezzelani } \\
\text { et al., 2016a; } \\
\text { Mezzelani } \\
\text { et al., } 2018\end{array}$ \\
\hline
\end{tabular}


Table 1. Cont

\begin{tabular}{|c|c|c|c|}
\hline Xenobiotics & Target Tissues & Assays & References \\
\hline Carbamazepine (drug) & Whole animal & $\begin{array}{l}\text { Measurement of glycogen and protein } \\
\text { levels; electron transport system; lipid } \\
\text { peroxidation; activity of superoxide } \\
\text { dismutase (SOD), catalase, glutathione } \\
\text { S-transferase, glutathione reductase, } \\
\text { and cytochrome P4503A4 enzymes }\end{array}$ & $\begin{array}{l}\text { Oliveira et al., } \\
2017\end{array}$ \\
\hline $\begin{array}{l}\text { Quaternium-15 } \\
\text { (preservative) }\end{array}$ & Digestive gland and gills & $\begin{array}{l}\text { Volume decrease adjustment (RVD); } \\
\text { analysis of ROS, TBARS, GSH/GSSG } \\
\text { and HSP70, superoxide dismutase } \\
\text { (SOD) enzyme activity }\end{array}$ & $\begin{array}{l}\text { Pagano et al., } \\
\text { 2016; } \\
\text { Faggio et al., } \\
2016\end{array}$ \\
\hline $\begin{array}{l}\text { Polyethylene and } \\
\text { polyester (microplastics) }\end{array}$ & Digestive gland and gills & $\begin{array}{l}\text { Measurement of } \\
\text { granulocyte/hyalinocyte ratio, } \\
\text { phagocytosis activity and stability of the } \\
\text { lysosomal membrane of hemocytes, } \\
\text { activity of acetylcholinesterase enzymes, } \\
\text { acyl-CoA oxidase, antioxidant enzymes, } \\
\text { lysosome latency (LP), } \\
\text { malondialdehyde and lipofuscin, DNA } \\
\text { and nucleus integrity }\end{array}$ & $\begin{array}{l}\text { Avio et al., } \\
2015\end{array}$ \\
\hline $\begin{array}{l}\text { Cadmium chloride } \\
(\mathrm{CdCl} 2) \text { and zinc } \\
\text { chloride ( } \mathrm{ZnCl} 2) \text { (heavy } \\
\text { metals) }\end{array}$ & $\begin{array}{l}\text { Digestive gland and } \\
\text { hemolymph }\end{array}$ & $\begin{array}{l}\text { Cell viability and stability of the } \\
\text { lysosomal membrane }\end{array}$ & $\begin{array}{l}\text { Pagano et al., } \\
2017\end{array}$ \\
\hline $\begin{array}{l}\text { Atrazine, pendimetalin, } \\
\text { fipronil, permethrin, } \\
\text { chlorothalonid, } \\
\text { propiconazole, and } \\
\text { pyraclostrobin } \\
\text { (pesticides) }\end{array}$ & Gills & $\begin{array}{l}\text { Changes in the growth of organisms } \\
\text { taken at an early stage of life }\end{array}$ & $\begin{array}{l}\text { Bringolf et al., } \\
2007\end{array}$ \\
\hline Glyphosate (herbicide) & $\begin{array}{l}\text { Digestive gland, gills, } \\
\text { and hemolymph }\end{array}$ & $\begin{array}{l}\text { Superoxide dismutase (SOD), catalase, } \\
\text { glutathione peroxidase, glutathione } \\
\text { S-transferase, alkaline phosphatase, and } \\
\text { acetylcholinesterase enzymes; DNA } \\
\text { integrity }\end{array}$ & $\begin{array}{l}\text { Matozzo } \\
\text { et al., 2018; } \\
\text { Milan et al., } \\
2018\end{array}$ \\
\hline $\begin{array}{l}\text { Imidacloprid and } \\
\text { Thiacloprid } \\
\text { (neonicotinoids) }\end{array}$ & Digestive gland and gills & $\begin{array}{l}\text { Stability of the lysosomal membrane } \\
\text { and activity of the acetylcholinesterase } \\
\text { enzyme }\end{array}$ & $\begin{array}{l}\text { Dondero } \\
\text { et al., 2010; } \\
\text { Prosser et al., } \\
2016\end{array}$ \\
\hline $\begin{array}{l}\text { Thiacloprid } \\
\text { (neonicotinoid) }\end{array}$ & $\begin{array}{l}\text { Digestive gland, gills, } \\
\text { and hemolymph }\end{array}$ & $\begin{array}{l}\text { Activity of superoxide dismutase (SOD), } \\
\text { glutathione reductase, glutathione } \\
\text { S-transferase, and catalase enzymes; } \\
\text { morphological and histological } \\
\text { anomalies, cell viability }\end{array}$ & $\begin{array}{l}\text { Stara et al., } \\
2020\end{array}$ \\
\hline $\begin{array}{l}\text { Calypso (insecticide with } \\
\text { Thiacloprid) }\end{array}$ & $\begin{array}{l}\text { Digestive gland, gills, } \\
\text { and hemolymph }\end{array}$ & $\begin{array}{l}\text { Determination of hemolymphatic } \\
\text { parameters; activity of superoxide } \\
\text { dismutase (SOD) and catalase enzymes }\end{array}$ & $\begin{array}{l}\text { Stara et al., } \\
2020\end{array}$ \\
\hline $\begin{array}{l}\text { Endosulfan, Aroclor } 1242 \\
\text { and 1254, DDT, Carbaril, } \\
\text { and Metrifonato } \\
\text { (pesticides and PCBs, i.e., } \\
\text { polychlorinated } \\
\text { biphenyls) }\end{array}$ & $\begin{array}{l}\text { Foot and byxogenic } \\
\text { gland }\end{array}$ & Formation of the byssus & Roberts, 1975 \\
\hline
\end{tabular}

\section{Conclusions}

Being a vast and heterogeneous phylum, mollusks play a crucial role in their living environment. They also represent an important link in the trophic chain, behaving differently from herbivores and 
predators, depending on the species. We can affirm that among the classes belonging to this phylum, there is one that is of particular interest for monitoring studies on neonicotinoids, namely, the bivalves. More precisely, the model organism that has been taken into consideration, and whose validity has been demonstrated, is M. galloprovincialis. Considering its ability to concentrate high levels of xenobiotics in tissues, and also considering its low detoxification enzymatic activity, it is useful to use this organism as a model to trace the levels of environmental contamination [73]. Several studies, through different types of analyses, have shown the effects of various xenobiotics and neonicotinoids on non-target organisms such as M. galloprovincialis.

Mytilus galloprovincialis is, therefore, important in the study of the environmental effects of neonicotinoids, because, being a filter organism, it can easily come into contact with these substances and accumulate this type of pollutants and, moreover, it can become dangerous for human health by entering its food chain.

Unfortunately, we cannot hide the difficulty in making progress in the study of environmental and health risks associated with neonicotinoids, because conflicts of interest between science, politics, and technology can inevitably emerge, so much so that a few years ago an international working group was formed, namely, the "Task Force on Systemic Pesticides." This task force works with two conditions: multidisciplinary, i.e., the possibility for different entities to confront each other, and independence from the constraints imposed by higher entities. Studies on neonicotinoids are fundamental, and we can carry them out thanks to a series of model organisms, such as M. galloprovincialis.

Funding: This research received no external funding.

Conflicts of Interest: The authors declare no conflict of interest.

\section{References}

1. Guruge, K.S.; Tanabe, S. Contamination by persistent organochlorines and butyltin compounds in the west coast of Sri Lanka. Mar. Pollut. Bull. 2001, 42, 179-186. [CrossRef]

2. Sánchez-Bayo, F. Insecticides mode of action in relation to their toxicity to non-target organisms. J. Environ. Anal. Toxicol. 2012, S4, 002.

3. Aliko, V.; Biba, A. Micronuclei induction in ranidae $\mathcal{E}$ buffonidae tadpoles by the pirethroid insecticide lambda-cyhalothrin. J. Ecosyst. Ecol. Sci. 2011, 1, 43-48.

4. Cataño, H.C.; Carranza, E.; Huamaní, C.; Hernández, A.F. Plasma cholinesterase levels and health symptoms in Peruvian farm workers exposed to organophosphate pesticides. Arch. Environ. Contam. Toxicol. 2008, 55, 153-159. [CrossRef]

5. Konradsen, F.; van der Hoek, W.; Cole, D.C.; Hutchinson, G.; Daisley, H. Reducing acute poisoning in developing countries-Options for restricting the availability of pesticides. Toxicology 2003, 192, 249-261. [CrossRef]

6. Walker, C.H. Organic Pollutants; Taylor \& Francis: Glasgow, UK, 2011.

7. Jeschke, P.; Nauen, R.; Schindler, M.; Elbert, A. Overview of the status and global strategy for neonicotinoids. J. Agric. Food Chem. 2011, 59, 2897-2908. [CrossRef]

8. Goulson, D. An overview of the environmental risks posed by neonicotinoid insecticides. J. Appl. Ecol. 2013, 50, 977-987. [CrossRef]

9. Tapparo, A.; Marton, D.; Giorio, C.; Zanella, A.; Solda, L.; Marzaro, M. Assessment of the environmental exposure of honeybees to particulate matter containing neonicotinoid insecticides coming from corn coated seeds. Environ. Sci. Technol. 2012, 46, 2592-2599. [CrossRef]

10. Marzaro, M.; Vivan, L.; Targa, A.; Mazzon, L.; Mori, N.; Greatti, M. Lethal aerial powdering of honey bees with neonicotinoids from fragments of maize seed coat. Bull. Insect. 2011, 64, 119-126.

11. Krupke, C.H.; Hunt, G.J;; Eitzer, B.D.; Andino, G.; Given, K. Multiple routes of pesticide exposure for honey bees living near agricultural fields. PLoS ONE 2012, 7, e29268. [CrossRef]

12. Connolly, C. Nerve agents in honey. Sci. Perspect. 2017, 358, 38-39. [CrossRef] [PubMed]

13. Hoar, J. The neonicotinoid era: The case for monitoring insecticide use on bee-attractive crops. BBKA Newws Incorporating The British Bee Journal, 20 April 2018. 
14. Goulson, D.; Lye, G.C.; Darvill, B. Decline and conservation of bumblebees. Annu. Rev. Entomol. 2008, 53, 191-208. [CrossRef] [PubMed]

15. Moritz, R.F.A.; de Miranda, J.; Fries, I.; Le Cont, Y.; Neumann, P.; Paxton, R.J. Research strategies to improve honeybee health in Europe. Apidologie 2010, 41, 227-242. [CrossRef]

16. Dussaubat, C. Lo stress combinato di pesticidi neonicotinoidi e parassiti altera la fisiologia e la sopravvivenza delle regine delle api. Sci. Rep. 2016, 6, 31430. [CrossRef]

17. Lechnet, M. Reducing pesticide use while preserving crop productivity and profitability on arable farms. Nat. Plants 2017, 3, 17008.

18. Boyd, I.L. An inside view on pesticide policy. Nat. Ecol. Evol. 2018, 2, 920-921. [CrossRef]

19. Simon-Delso, N.; Amaral-Rogers, V. Systemic insecticides (neonicotinoids and fipronil): Trends, uses, mode of action and metabolites. Environ. Sci. Pollut. Res. 2015, 22, 5-34. [CrossRef]

20. Velisek, J.; Stara, A. Effect of thiacloprid on early life stages of common carp (Cyprinus carpio). Chemosphere 2018, 194, 481-487. [CrossRef]

21. Tomizawa, M.; Casida, J.E. Neonicotinoid insecticides: Highlights of a symposium on strategic molecular designs. J. Agric. Food Chem. 2011, 59, 2883-2886. [CrossRef]

22. Chen, M.F.; Huang, J.W.; Wong, S.W.; Li, G.C. Analysis of insecticide clothianidin and its metabolites in rice by liquid chromatography with a UV detector. J. Food Drug Anal. 2005, 13, 279-283.

23. Ford, K.A.; Casida, J.E. Comparative metabolism and pharmacokinetics of seven neonicotinoid insecticides in spinach. J. Agric. Food Chem. 2008, 56, 10168-10175. [CrossRef]

24. Casida, J.E. Neonicotinoid metabolism: Compounds, substituents, pathways, enzymes, organisms and relevance. J. Agric. Food Chem. 2011, 59, 2923-2931. [CrossRef]

25. Ford, K.A.; Casida, J.E. Unique and common metabolites of thiamethoxam, clothianidin, and dinotefuran in mice. Chem. Res. Toxicol. 2006, 19, 1549-1556. [CrossRef]

26. Schulz-Jander, D.A.; Casida, J.E. Imidacloprid insecticide metabolism: Human cytochrome P450 isozymes differ in selectivity for imidazolidine oxidation versus nitroimine reduction. Toxicol. Lett. 2002, 132, 65-70. [CrossRef]

27. Shi, X.; Dick, R.A.; Ford, K.A.; Casida, J.E. Enzymes and inhibitors in neonicotinoid insecticide metabolism. J. Agric. Food Chem. 2009, 57, 4861-4866. [CrossRef]

28. Shao, X.; Liu, Z.; Xu, X.; Li, Z.; Qian, X. Overall status of neonicotinoid insecticides in China: Production, application and innovation. J. Pest Sci. 2003, 38, 1-9. [CrossRef]

29. Andersch, W.; Jeschke, P.; Thielert, W. Combination of Methiocarb and One or More Compounds Selected from Thiacloprid, Thiamethoxam, Acetamiprid, Nitenpyram, and Dinotefuran; Effective Animal Pests Control and for Plant Seed Dressing; Bayer Crop Science AG: Monheim am Rhein, Germany, 2010.

30. Iwasa, T.; Motoyama, N.; Ambrose, J.T.; Roe, R.M. Mechanism for the differential toxicity of neonicotinoid insecticides in the honey bee, Apis mellifera. Crop. Prot. 2004, 23, 371-378. [CrossRef]

31. Morrissey, C.A.; Mineau, P.; Devries, J.H.; Sanchez-Bayo, F.; Liess, M.; Cavallaro, M.C.; Liber, K. Neonicotinoid contamination of global surface waters and associated risk to aquatic invertebrates: A review. Environ. Int. 2015, 74, 291-303. [CrossRef]

32. Wachendorff-Neumann, U.; Mauler-Machnik, A.; Erdelen, C.; Ohtake, H. Synergistic Mixture of Trifloxystrobin and Imidacloprid; Bayer Cropscience AG: Montvale, NJ, USA, 2012.

33. Marigómez, I.; Zorita, I.; Izagirre, U.; Ortiz-Zarragoitia, M.; Navarro, P.; Etxebarria, N.; Orbea, A.; Soto, M.; Cajaraville, M.P. Combined use of native and caged mussels to assess biological effects of pollution through the integrative biomarker approach. Aquat. Toxicol. 2013, 136-137, 32-48. [CrossRef] [PubMed]

34. Viarengo, A.; Lowe, D.; Bolognesi, C.; Fabbri, E.; Koehler, A. The use of biomarkers in biomonitoring: A 2-tier approach assessing the level of pollutant-induced stress syndrome in sentinel organisms. Comp. Biochem. Physiol. 2007, 146, 281-300. [CrossRef]

35. Capolupo, M.; Valbonesi, P.; Kiwan, A.; Buratti, S.; Franzellitti, S.; Fabbri, E. Use of an integrated biomarker-based strategy to evaluate physiological stress responses induced by environmental concentrations of caffeine in the Mediterranean mussel Mytilus galloprovincialis. Sci. Total Environ. 2016, 563-564, 538-548. [CrossRef] [PubMed]

36. Livinstone, D.R. Organic xenobiotic metabolism in marine invertebrates. Adv. Comp. Environ. Physiol. 1991, $7,45-185$. 
37. Torre, A.; Trischitta, F.; Faggio, C. Effect of $\mathrm{CdCl}_{2}$ on regulatory volume decrease (RVD) in Mytilus galloprovincialis digestive cells. Toxicol. In Vitro 2013, 27, 1260-1266. [CrossRef]

38. Faggio, C.; Tsarpali, V.; Dailianis, S. Mussel digestive gland as a model tissue for assessing xenobiotics: An overview. Sci. Total Environ. 2018, 636, 220-229. [CrossRef]

39. Freitas, R.; Silvestro, S.; Pagano, M.; Coppola, F.; Meucci, V.; Battaglia, F.; Intorre, L.; Soares, A.M.V.M.; Faggio, C. Impacts of salicylic acid in Mytilus galloprovincialis exposed to warming conditions. Environ. Toxicol. Pharmacol. 2020, 80, 103448. [CrossRef]

40. Freitas, R.; Silvestro, S.; Coppola, F.; Meucci, V.; Battaglia, F.; Intorre, L.; Soares, A.M.V.M.; Pretti, C.; Faggio, C. Combined effects of salinity changes and salicylic acid exposure in Mytilus galloprovincialis. Sci. Total Environ. 2020, 715, 136804. [CrossRef]

41. Freitas, R.; Silvestro, S.; Coppola, F.; Costa, S.; Meucci, V.; Battaglia, F.; Intorre, L.; Soares, A.M.V.M.; Pretti, C.; Faggio, C. Toxic impacts induced by sodium lauryl sulfate in Mytilus galloprovincialis. Comp. Biochem. Physiol. Part A Mol. Integr. Physiol. 2020, 242, 110656. [CrossRef] [PubMed]

42. Freitas, R.; Silvestro, S.; Coppola, F.; Meucci, V.; Battaglia, F.; Intorre, L.; Soares, A.M.V.M.; Pretti, C.; Faggio, C. Biochemical and physiological responses induced in Mytilus galloprovincialis after a chronic exposure to salicylic acid. Aquatic Toxicol. 2019, 214, 105258. [CrossRef] [PubMed]

43. Depledge, M.H. The rational basis for the use of biomarkers as ecotoxicological tools. In Nondestructive Biomarkers in Vertebrates; Fossi, M.C., Leonzio, C., Eds.; Lewis Publishers: Boca Raton, FL, USA, 1993; pp. 261-285.

44. Burgos-Aceves, M.A.; Faggio, C. An approach to the study of the immunity functions of bivalve haemocytes: Physiology and molecular aspects. Fish Shellfish Immunol. 2017, 67, 513-517. [CrossRef]

45. Boillot, C.; Martinez Bueno, M.J.; Munaron, D.; Le Dreau, M.; Mathieu, O.; Davida, A.; Fenet, H.; Casellas, C.; Gomez, E. In vivo exposure of marine mussels to carbamazepine and 10-hydroxy-10, 11-dihydro-carbamazepine: Bioconcentration and metabolization. Sci. Total Environ. 2015, 532, 564-570. [CrossRef] [PubMed]

46. Orbea, A.; Garmendia, L.; Marigómez, I.; Cajaraville, M.P. Effects of the 'Prestige' oil spill on cellular biomarkers in intertidal mussels: Results of the first year of studies. Mar. Ecol. Prog. Ser. 2006, 306, 177-189. [CrossRef]

47. Davenport, J.; Manley, A. The detection of heightened sea-water copper concentrations by the mussel Mytilus edulis. J. Mar. Biol. Assoc. UK 1978, 58, 843-850. [CrossRef]

48. Sloof, W.; deZwart, D.; Marquenie, J.M. Detection limits of a biological monitoring system for chemical water pollution based on mussel activity. Bull. Environ. Contam. Toxicol. 1983, 30, 400-405. [CrossRef] [PubMed]

49. Kramer, K.J.M.; Jenner, H.A.; deZwart, D. The valve movement response of mussels: A tool in biological monitoring. Hydrobiologia 1989, 188/189, 433-443. [CrossRef]

50. Santovito, G.; Piccinni, E.; Cassini, A.; Irato, P.; Albergoni, V. Antioxidant responses of the Mediterranean mussel, Mytilus galloprovincialis, to environmental variability of dissolved oxygen. Comp. Biochem. Physiol. C 2005, 140, 321-329. [CrossRef]

51. Braby, C.E.; Somero, G.N. Following the heart: Temperature and salinity effects on heart rate in native and invasive species of blue mussels (genus Mytilus). J. Exp. Biol. 2009, 209, 2554-2566. [CrossRef] [PubMed]

52. Larguinho, M.; Cordeiro, A.S.; Diniz, M.M.; Costa, P.V.; Baptista, P. Metabolic and histopathological alterations in the marine bivalve Mytilus galloprovincialis induced by chronic exposure to acrylamide. Environ. Res. 2014, 135, 55-62. [CrossRef]

53. Kahle, J.; Zauke, G.P. Bioaccumulation of trace metals in the calanoid copepod Metridia gerlachei from the Weddell Sea (Antarctica). Sci. Total Environ. 2002, 295, 1-16. [CrossRef]

54. Azizi, G.; Akodad, M.; Baghour, M.; Layachi, M.; Moumen, A. The use of Mytilus spp. mussels as bioindicators of heavy metal pollution in the coastal environment. A review. J. Mater. Environ. Sci. 2018, 9, 1170-1181.

55. Aarab, N.; Lemaire-Gony, S.; Unruh, E.; Hansen, P.D.; Larsen, B.K.; Andersen, O.K.; Narbonne, J.F. Preliminary study of responses in mussel (Mytilus edulis) exposed to bisphenol A, di allyl phthalate and tetrabromodiphenyl ether. Aquat. Toxicol. 2006, 78S, S86-S92. [CrossRef] [PubMed]

56. Tedesco, S.; Doyle, H.; Blasco, J.; Redmond, G.; Sheehan, D. Oxidative stress and toxicity of gold nanoparticles in Mytilus edulis. Aquat. Toxicol. 2010, 100, 178-186. [CrossRef] [PubMed]

57. Canesi, L.; Ciacci, C.; Fabbri, R. Bivalve molluscs as a unique target group for nanoparticle toxicity. Mar. Environ. Res. 2012, 76, 16-21. [CrossRef] [PubMed] 
58. Qyli, M.; Aliko, V.; Faggio, C. Physiological and Biochemical Responses of Mediterranean Green Crab, Carcinus aestuarii, to Different Environmental Stressors: Evaluation of Haemocyte Toxicity and Its Possible Effects on Immune Response. Comp. Biochem. Physiol. C 2020, 231, 108739. [CrossRef]

59. Canesi, L.; Lorusso, L.C.; Ciacci, C.; Betti, M.; Regoli, F.; Poiana, G.; Gallo, G.; Marcomini, A. Effects of blood lipid lowering pharmaceuticals (bezafibrate and gemfibrozil) on immune and digestive gland functions of the bivalve mollusc, Mytilus galloprovincialis. Chemosphere 2007, 69, 994-1002. [CrossRef]

60. Lacaze, E.; Pédelucq, J.; Fortier, M.; Brousseau, P.; Auffret, M.; Budzinski, H.; Fournier, M. Genotoxic and immunotoxic potential effects of selected psychotropic drugs and antibiotics on blue mussel (Mytilus edulis) hemocytes. Environ. Poll. 2015, 202, 177-186. [CrossRef]

61. Martin-Diaz, L.; Franzellitti, S.; Buratti, S.; Valbonesi, P.; Capuzzo, A.; Fabbri, E. Effects of environmental concentrations of the antiepilectic drug carbamazepine on biomarkers and cAMP-mediated cell signaling in the mussel Mytilus galloprovincialis. Aquat. Toxicol. 2009, 94, 177-185. [CrossRef]

62. Tsiaka, P.; Tsarpali, V.; Ntaikou, I.; Kostopoulou, M.N.; Lyberatos, G.; Dailianis, S. Carbamazepine-mediated pro-oxidant effects on the unicellular marine algal species Dunaliella tertiolecta and the hemocytes of mussel Mytilus galloprovincialis. Ecotoxicology 2013, 22, 1208-1220. [CrossRef]

63. Mezzelani, M.; Gorbi, S.; Da Ros, Z.; Fattorini, D.; d’Errico, G.; Milan, M.; Bargelloni, L.; Regoli, F. Ecotoxicological potential of non-steroidal anti-inflammatory drugs ((NSAIDs)) in marine organisms: Bioavailability, biomarkers and natural occurrence in Mytilus galloprovincialis. Mar. Environ. Res. 2016, 121, 31-39. [CrossRef]

64. Mezzelani, M.; Gorbi, S.; Fattorini, D.; d’Errico, G.; Benedetti, M.; Milan, M.; Bargelloni, L.; Regoli, F. Transcriptional and cellular effects of Non-Steroidal Anti-Inflammatory Drugs ((NSAIDs)) in experimentally exposed mussels, Mytilus galloprovincialis. Aquat. Toxicol. 2016, 180, 306-319. [CrossRef]

65. Toufexi, E.; Dailianis, S.; Vlastos, D.; Manariotis, D.I. Mediated effect of ultrasound treated Diclofenac on mussel hemocytes: First evidence for the involvement of respiratory burst enzymes in the induction of DCF-mediated unspecific mode of action. Aquat. Toxicol. 2016, 175, 144-153. [CrossRef] [PubMed]

66. Politakis, N.; Belavgeni, A.; Efthimiou, I.; Charalampous, N.; Kourkouta, C.; Dailianis, S. The impact of expired commercial drugs on non-target marine species: A case study with the use of a battery of biomarkers in hemocytes of mussels. Ecotoxicol. Environ. Safety 2018, 148, 160-168. [CrossRef] [PubMed]

67. Pagano, M.; Capillo, G.; Sanfilippo, M.; Palato, S.; Trischitta, F.; Manganaro, A.; Faggio, C. Evaluation of functionality and biological responses of Mytilus galloprovincialis after exposure to Quaternium-15 (Methenamine 3-Chloroallylochloride). Molecules 2016, 21, 144. [CrossRef]

68. Aliko, V.; Faggio, C.; Hajdaraj, G.; Caci, A. Copper induced lysosomal membrane destabilisation in haemolymph cells of crab (Carcinus aestuarii, nardo, 1847) from the Narta Lagoon (Albania). Braz. Arch. Biol. Technol. 2015, 58, 750-756. [CrossRef]

69. Pizzimenti, S.; Toaldo, C.; Pettazzoni, P.; Dianzani, M.U.; Barrera, G. The "two-faced" effects of reactive oxygen species and the lipid peroxidation product 4- hydroxynonenal in the hallmarks of cancer. Cancers 2010, 2, 338-363. [CrossRef]

70. Lushchak, V.I. Environmentally induced oxidative stress in aquatic animals. Aquat. Toxicol. 2011, 101, 13-30. [CrossRef]

71. Lushchak, V.I. Free radicals, reactive oxygen species, oxidative stress and its classification. Chem. Biol. Interact. 2014, 224, 164-175. [CrossRef]

72. Faggio, C.; Pagano, M.; Alampi, R.; Vazzana, I.; Felice, M.R. Cytotoxicity, haemolymphatic parameters, and oxidative stress following exposure to sub-lethal concentrations of quaternium-15 in Mytilus galloprovincialis. Acquat. Toxicol. 2016, 180, 258-265. [CrossRef]

73. Widdow, S.; Donkin, P. Mussels and environmental contaminants: Bioaccumulation and physiological aspects. In The Mussel Mytilus: Ecology, Physiology, Genetics and Culture; Gosling, Elsevier: Amsterdam, The Netherlands, 1992; pp. 383-424.

74. Torre, A.; Trischitta, F.; Corsaro, C.; Mallamace, D.; Faggio, C. Digestive cells from Mytilus galloprovincialis show a partial regulatory volume decrease following acute hypotonic stress through mechanisms involving inorganic ions. Cell Biochem. Funct. 2013, 31, 489-495. [CrossRef]

75. Avio, C.G.; Gorbi, S.; Milan, M.; Benedetti, M.; Fattorini, D.; d'Errico, G.; Pauletto, M.; Bargelloni, L.; Regoli, F. Pollutants bioavailability and toxilogical risk from microplastics to marine mussels. Environ. Poll. 2015, 198, 211-222. [CrossRef] 
76. Milan, M.; Dalla Rovere, G.; Smits, M.; Ferraresso, S.; Pastore, P.; Marin, M.G.; Bogialli, S.; Patarnello, T.; Bargelloni, L.; Matozzo, V. Ecotoxicological effects of the herbicide glyphosate in non-target aquatic species: Transcriptional responses in the mussel Mytilus galloprovincialis. Environ. Poll. 2018, 237, 442-451. [CrossRef] [PubMed]

77. Oliveira, P.; Almeida, A.; Calisto, V.; Esteves, V.I.; Schneider, R.J.; Wrona, F.J.; Soares, A.M.V.M.; Figueira, E.; Freitas, R. Physiological and biochemical alterations induced in the mussel Mytilus galloprovincialis after short and long-term exposure to carbamazepine. Water Res. 2017, 117, 102-114. [CrossRef] [PubMed]

78. Burgos-Aceves, M.A.; Abo-Al-Ela, H.G.; Faggio, C. Physiological and metabolic approach of plastic additives effects: Immune cells responses. J. Hazar Mater. 2020, 404, 124114. [CrossRef]

79. Abo-Al-Ela, H.G.; Faggio, C. MicroRNA-mediated stress response in bivalve species. Ecotoxicol. Environ. Saf. 2021, 208, 111442. [CrossRef]

80. Dimitriadis, V.K.; Domouhtsidou, G.P.; Cajaraville, M.P. Cytochemical and histochemical aspects of the digestive gland cells of the mussel Mytilus galloprovincialis (L.) in relation to function. J. Mol. Histol. 2004, 35, 501-509. [CrossRef]

81. Marigómez, I.; Soto, M.; Cajaraville, M.P.; Angulo, E.; Giamberini, L. Cellular and subcellular distribution of metals in molluscs. Microsc. Res. Tech. 2002, 56, 358-392. [CrossRef]

82. Pagano, M.; Porcino, C.; Briglia, M.; Fiorino, E.; Vazzana, M.; Silvestro, S.; Faggio, C. The influence of exposure of cadmium chloride and zinc chloride on haemolymph and digestive gland cells from Mytilus galloprovincialis. Int. J. Environ. Res. 2017, 11, 207-216. [CrossRef]

83. De Oliveira David, J.A.; Salaroli, R.B.; Fontanetti, C.S. The significance of changes in Mytella falcata gill filaments chronically exposed to polluted environments. Micron 2008, 39, 1293-1299. [CrossRef] [PubMed]

84. Carella, F. Biotechnologies to Evaluate the Environmental Status: New Test Organisms in Ecotoxicology and Histopathological and Molecular Biomarkers in Natural Population. Ph.D. Thesis, University of Naples Federico II, Naples, Italy, 2010.

85. George, S.G.; Pirie, B.J.S.; Coombs, T.L. The kinetics of accumulation and excretion of ferric hydroxide in Mytilus edulis (I.) and its distribution in the tissues. Exp. Mar. Biol. Ecol. 1976, 23, 71. [CrossRef]

86. Regoli, F.; Nigro, M.; Orlando, F. Effects of copper and cadmium on the presence of renal concretions in the bivalve Donacilla cornea. Comp. Biochem. Phys. 1992, 102C, 189. [CrossRef]

87. Tripp, M.R. Disposal by the oyster of intracardially injected red blood cells of vertebrates. Proc. Natl. Shellfish. Assoc. 1957, 48, 143.

88. Dondero, F.; Negri, A.; Boatti, L.; Marsano, F.; Mignone, F.; Viarengo, A. Transcriptomic and proteomic effects of a neonicotinoid insecticide mixture in the marine mussel (Mytilus galloprovincialis, Lam.). Sci. Total Environ. 2010, 408, 3775-3786. [CrossRef]

89. Stara, A.; Pagano, M.; Capillo, G.; Fabrello, J.; Sandova, M.; Vazzana, I.; Zuskova, E.; Velisek, J.; Matozzo, V.; Faggio, C. Assessing the effects of neonicotinoid insecticide on the bivalve mollusc Mytilus galloprovincialis. Sci. Total Environ. 2020, 700, 134914. [CrossRef]

90. Beketov, M.A.; Liess, M. Acute and delayed effects of the neonicotinoid insecticide thiacloprid on seven freshwater arthropods. Environ. Toxicol. Chem. 2008, 27, 461-470. [CrossRef]

91. Prosser, R.S.; de Solla, S.R.; Holman, E.A.M.; Osborne, R.; Robinson, S.A.; Bartlett, A.J.; Maisonneuve, F.J.; Gillis, P.L. Sensitivity of the early-life stages of freshwater mollusks to neonicotinoid and butenolide insecticides. Environ. Pollut. 2016, 218, 428-435. [CrossRef]

92. EPA (Environmental Protection Agency). Name of Chemical: Thiacloprid Reason for Issuance: Conditional Registration Date Issued: September 26, 2003; Office of Prevention and Toxic Substances (7501C), Oregon State: Salem, OR, USA, 2003.

93. Stara, A.; Pagano, M.; Capillo, G.; Fabrello, J.; Sandova, M.; Albano, M.; Zuskova, E.; Velisek, J.; Matozzo, V.; Faggio, C. Acute effects of neonicotinoid insecticides on the Mediterranean mussel Mytilus galloprovincialis: A case study with the active compound thiacloprid and the commercial formulation Calypso 480 SC. Ecotoxicol. Environ. Safety 2020, 203, 110980. [CrossRef]

94. EFSA (European Food Safety Authority). EFSA Identifies Risks to Bees from Neonicotinoids; EFSA: Parma, Italy, 2013.

95. McCaffery, A.; Nauen, R. The insecticide resistance action committee (IRAC): Public responsibility and enlightened industrial self-interest. Outlooks Pest Manag. 2006, 17, 11-14. 
96. Mileson, B.E.; Chambers, J.E.; Chen, W.L.; Dettbarn, W.; Ehrich, M.; Eldefrawi, A.T.; Gaylor, D.W.; Hamernik, K.; Hodgson, E.; Karczmar, A.G.; et al. Common mechanism of toxicity: A case study of organophosphorus pesticides. Toxicol. Sci. 1998, 41, 8-20.

97. Roberts, D. The effect of pesticides on byssus formation in the common musel, Mytilus edulis. Environ. Pollut. 1975, 8, 241-254. [CrossRef]

98. Bell, E.C.; Gosline, J.M. Mechanical design of mussel byssus: Material yield enhances attachment strength. J. Exp. Biol. 1996, 199, 1005-1017. [PubMed]

99. Burnett, N.P.; Sara, G. Functional responses of intertidal bivalves to repeated sub-lethal, physical disturbances. Mar. Environ. Res. 2019, 147, 32-36. [CrossRef] [PubMed]

100. Ayad, M.A.; Fdil, M.A.; Mouabad, A. Effects of cypermethrin (pyrethroid insecticide) on the valve activity behavior, byssal thread formation, and survival in air of the marine mussel Mytilus galloprovincialis. Arch. Environ. Contam. Toxicol. 2011, 60, 462-470. [CrossRef] [PubMed]

101. Savorelli, F.; Manfra, L.; Croppo, M.; Tornambe, A.; Palazzi, D.; Canepa, S.; Trentini, P.L.; Cicero, A.M.; Faggio, C. Fitness evaluation of Ruditapes philippinarum exposed to nickel. Biol. Trace Elem. Res. 2017, 177, 384-393. [CrossRef] [PubMed]

102. Chmist, J.; Szoszkiewicz, K.; Drozdzynski, D. Behavioural responses of Unio tumidus freshwater mussels to pesticide contamination. Arch. Environ. Contam. Toxicol. 2019, 77, 432-442. [CrossRef]

Publisher's Note: MDPI stays neutral with regard to jurisdictional claims in published maps and institutional affiliations. 